\title{
Intraspecific variations in cardamom (Elettaria cardamomum Maton): assessment of genomic diversity by flow cytometry, cytological studies and ISSR analysis
}

\author{
N. Anjali, K. M. Ganga, F. Nadiya, S. Shefeek and K. K. Sabu* (i)
}

\begin{abstract}
Background: The main goal of the work was to analyse intraspecific variation in Elettaria cardamomum Maton (cardamom) using genome size, cytological studies and molecular marker data. Nuclear DNA content and molecular marker details furnish data on genome size and genetic diversity respectively among the studied accessions and both complement each other for evolutionary and taxonomic studies.

Results: The relative $2 \mathrm{C}$ genome size and total number of base pairs of cardamom was determined through flow cytometric analysis using propidium iodide staining. The nuclear DNA content was estimated in various sections of the species representing individuals from wild and cultivar genotypes following Zea mays L. CE-777 $(2 C=5.43 \mathrm{pg})$ as internal reference standard. Chromosome number from growing root tip was examined following standard protocols. Twenty-six ISSR primers that generated polymorphic bands were used for genetic diversity analysis of the thirty accessions of cardamom. Estimated nuclear 2C DNA content ranged from 2.57 to $3.22 \mathrm{pg}$ demonstrating 1.25 -fold variation. The mean amount of $2 \mathrm{C}$ nuclear DNA of the cardamom was calculated as $2.87 \mathrm{pg}$ which is equivalent of $2806 \mathrm{Mbp}$ as the diploid genome size. The chromosome number was found to be $2 n=48$. Among the thirty accessions of cardamom studied using ISSR markers, C53 (feral from Bonacaud) showed a very prominent level of genetic diversity and was lowest for C96 (Avinash-I, a released variety from Indian Institute of Spices Research, Kozhikode).
\end{abstract}

Conclusion: These analyses revealed the existence of genetic variability within the studied cardamom accessions. The plant specimens also differed significantly in their genome size. However, the genetic variability parameters did not show any correlation with genome size.

Keywords: Cardamom, Genome size, Genetic variation, Flow cytometry, 2C value, Elettaria cardamomum Maton, Zingiberace, ISSR, EST-SSR

\section{Background}

Elettaria cardamomum Maton known as Queen of spices belongs to monocotyledonous family Zingiberaceae. This perennial rhizomatous plant is mainly confined to mid-elevations (600-1300 m a.s.l.) in the Western Ghats of South India (Ravindran and Madhusoodanan 2003). It is a shade loving plant and $40-50 \%$ shade promote its vegetative

\footnotetext{
*Correspondence: sabu@jntbgri.res.in

Biotechnology and Bioinformatics Division, Jawaharlal Nehru

Tropical Botanic Garden and Research Institute (JNTBGRI), Palode,

Thiruvananthapuram 695562, India
}

growth and development (Kumar et al. 2015). Dried fruit of small cardamom (commonly called as cardamom) is widely used for culinary and medicinal purposes. It is mainly used as a flavouring agent in food preparations and for the treatment of gastrointestinal disorders. D-Limonene, one of the constituent of cardamom oil is reported to have tumour suppressing effect against colon, mammary, liver, lung, skin and stomach cancers in rodents (Samir et al. 2015). It has been stated in a US patent (US 20060147561 A1) that a poly herbal formulation including cardamom can be efficiently used for diabetic treatment (Nitasha Bhat et al. 2015). 
Cardamom is indigenous to South India and Sri Lanka (Purseglove et al. 1981) and there is a strong belief that the species has been originated in the moist evergreen rainforests of the Western Ghats of South India (Kumar et al. 1997). According to reliable reports, cardamom cultivation began during 1803 in India and until then, cardamom pods were harvested from forests (Ravindran and Madhusoodanan 2003). This means that selection of cardamom with respect to better agronomic traits began around 210 years ago. Further, the cultivation was usually practised in forests after clearing all the undergrowth where cardamom grows naturally. These processes could have gradually eliminated wild cardamom as such and genetic variations there exist. Frequent cultivation of cardamom and targeted selection of peculiar morpho/ ecotypes have resulted in the development of many location specific landraces. As in the case of other crop plants, wild cardamom plants (including disease escapes (Venugopal 1999) from abandoned plantations) may have genetic variability and possess alleles that can be effectively used for crop improvement programmes.

Genetic diversity is the basis for development of elite varieties with desirable characteristics. Genetic diversity analysis can be performed using morphological, biochemical and molecular markers (Govindaraj et al. 2015). The biological diversity information which is important for efficacious conservation programmes have become refined by the usage of molecular techniques (Oliveira-Miranda et al. 2013). Molecular markers offer consistent results despite the prevailing environmental circumstances. Among the widely used markers, inter simple sequence repeat (ISSR) marker is a PCR based molecular marker in which a DNA region situated between two similar microsatellite motifs aligned in opposite directions got amplified (Mohammad et al. 2015). So the primers used in this case are microsatellite portions which are tandem repeats of di- to penta-nucleotides. Knowledge on DNA sequence of study organism is not needed for ISSR marker study and can be undertaken for any plant species (Prakashkumar et al. 2015).

ISSR polymorphism has been widely used all over the world to characterize plant genetic variations. It is reported that Iranian Hypericum perforatum L. wild population shows genetic diversity at the intraspecific level estimated using ISSR markers (Mohammad et al. 2015). ISSR profiling revealed $87 \%$ polymorphism in nine varieties of Ginkgo biloba (Zhiqiang et al. 2014). RAPD markers unravelled more information on genetic variability than ISSR markers in Justicia adhatoda L., Caldesia grandis and Dalbergia sissoo (Amit et al. 2014; Chen et al. 2006; Arif et al. 2009). High level of polymorphism was obtained for seven populations of Lemna gibba using five ISSR primers (Aziza et al. 2015). Remarkable level of polymorphism was detected among thirteen accessions of the medicinal plant Rauvolfia serpentina L. with fifteen ISSR primers (Padmesh et al. 2012).

Microsatellites occur in all plant genomes are studied widely for analyzing the genetic variations. They are abundant in non-coding genomic regions, but also detected in coding regions through studies using ESTSSRs (Ranade et al. 2014). For example, in EST databases, an EST-SSR occurs every $14 \mathrm{~kb}$ in Arabidopsis (Cardle et al. 2000) and every $19 \mathrm{~kb}$ in rice (Temnykh et al. 2001). In contrast to the genomic SSRs, EST-SSRs represent functional markers and changes in EST-SSRs length can cause a phenotypic effect (Li et al. 2004). The significance of EST-SSRs as a molecular tool in genetic studies is well known (Ellis and Burke 2007) and demonstrated in population studies and analysis of genetic diversity in Populus (Xinye et al. 2009); in hybrid selection in Citrus (Rao et al. 2008); and also in genetic mapping in Pinus (Echt et al. 2011) to mention a few. Furthermore, unlike the genomic SSRs, EST-SSRs are easily transferable across species (Kalia et al. 2011), therefore allowing studying polymorphism and genetic diversity in related species (Ellis and Burke 2007). Recently, it has been reported that microsatellites or simple sequence repeats from expressed sequence tags (EST-SSRs) of curcuma shows considerable genetic variation in cardamom (Anjali et al. 2015).

The plant cell nucleus consists of most of the hereditary material and has always been a subject of intensive studies. Nuclear DNA C-value is the amount of DNA incorporated within a haploid nucleus and is expressed in picograms $\left(1 \mathrm{pg} D N A=0.978 \times 10^{9} \mathrm{bp}\right)($ Dolezel et al . 2003). $2 \mathrm{C}$-value specifies the amount of DNA contained within two copies of unreplicated genome in a nucleus which is in the G1 phase of the cell cycle (Dolezel and Bartos 2005). The First plant genome size determination was done in Lilium longiflorum in the year 1951 (Pellicer and Leitch 2014). Measurement of nuclear DNA amount has paved the way for uncovering broad range of difference in genome size in various organisms (Dolezel et al. 2007). No correlation exists between the genome size and organismal complexity as the eukaryotic genomes consist of large quantities of non-protein coding DNA. Genome size of more than 15,000 species of animals, plants, fungi and protists has been estimated so far (Elliott and Gregory 2015). Kew plant DNA $\mathrm{C}$-value database is the depository for genome size data of plants (http://data.kew.org/cvalues/) and the commonly noticed genome size in Kew database is $500 \mathrm{Mb}$ (Michael 2014). Genome size in Angiosperms ranges from $0.129 \mathrm{pg}$ in Genlisea margaretae to $304.46 \mathrm{pg}$ in Paris japonica (Chen et al. 2014). The important element which determines the genome size is the number of repetitive sequences (Sakurako et al. 1997). Genome 
size is related to change in periodic biological phenomena of plants, responsiveness to frost, ecological fitting in response to availability of water and organism, tissue, cellular and sub cellular level characters like nuclear and cell volumes, mitotic and meiotic cycles span and seed weight (Suda et al. 2007). Genome size knowledge is required for designing gene cloning, small RNA and whole genome sequencing projects as their scale and cost are determined by genome size.

One of the main applications of flow cytometry is the estimation of genome size. The simplicity in sample preparation, fastness, precision, convenience and the potential to check large numbers of samples per day make flow cytometry an efficient method for estimating genome size in plants (Yue-ping et al. 2015). The first fluorescence based flow cytometer was developed by Wolfgang gohde in 1968. Flow cytometer aids in measurement and counting of particles in a constrained suspension and comprises of three components-fluidics, optics and electronics (Sergio 2008). When illuminated by an intense source of light, these particles absorb and scatter light. If the particles are tagged with any fluorescent dye, it emit fluorescent signals also. The fluorochromes tether stoichiometrically with nucleic acids so that number of probe molecules bound is comparable to the number of DNA molecules. The scattered light and fluorescent signals are perceived by dichroic mirrors, filters and photomultiplier tubes (Galbraith 2010). The software equipped with the instrument translates these signals into a graph in which fluorescent intensity is plotted against cell counts (Sergio 2006). The discovery of such an effortless and precised method for isolating nuclei from solid tissues becomes an innovation in flow cytometry of plant species (Loureiro et al. 2010). The nuclear DNA content of the reference standard used should not be too close or too distant from that of the unknown sample (Milene et al. 2011).

Nuclear DNA content and molecular marker details furnish data on genome size and genetic diversity among accessions respectively and both complement each other for evolutionary and taxonomic studies. In the present study, thirty accessions of cardamom were subjected to nuclear DNA content estimation by flow cytometry and genetic variability analysis using ISSR markers. To the best of our knowledge, this is a novel study using two types of techniques which complement each other in deciphering the genetic architecture of cardamom genome.

\section{Methods}

\section{Plant materials}

Thirty accessions of cardamom including wild collections (those from natural forests), landraces, feral and released varieties were used for genome size estimation and ISSR marker study. All the samples were obtained from the germplasm collection of authors' Institute. They were originally collected from different parts of Western ghats (Table 1). A portable GPS (Garmin, New Delhi) was used to document the geographic location of accessions collected.

Solanum lycopersicum L. Stupicke polni rane (2C DNA content is $1.96 \mathrm{pg}$ ), Glycine max Merr. Polanka (2C DNA content is $2.50 \mathrm{pg}$ ) and Zea mays L. CE-777 (2C DNA content is $5.43 \mathrm{pg}$ ) obtained from Laboratory of Molecular Cytogenetics and Cytometry, Institute of Experimental Botany, Sokolovska, Czech Republic were used as internal reference standards for genome size estimation study (Dolezel et al. 2007).

\section{Genome size determination using flow cytometry}

Samples were prepared according to a standard two step procedure (Otto 1990). About $50 \mathrm{mg}$ of young and fresh incompletely expanded leaf tissue of test sample and internal standard were co-chopped with a sharp razor blade in a plastic petridish containing $2 \mathrm{ml}$ of ice-cold Otto I buffer (0.1 M citric acid, $0.5 \%$ Tween 20$)$. This was kept at $-4{ }^{\circ} \mathrm{C}$ for $40 \mathrm{~min}$ for releasing nuclei from cells to buffer. The nuclear suspension was filtered through a $40 \mu \mathrm{m}$ Nylon mesh and centrifuged at $150 \mathrm{~g}$ for $5 \mathrm{~min}$. Nuclei were gently resuspended in $100 \mu \mathrm{l}$ of fresh Otto I buffer after removing the supernatant. $1 \mathrm{ml}$ of Otto II buffer $\left(0.4 \mathrm{M} \mathrm{Na}_{2} \mathrm{HPO}_{4} \cdot 12 \mathrm{H}_{2} \mathrm{O}\right)$ supplemented with propidium iodide for absolute DNA content determination and RNase (both at a final concentration of $100 \mu \mathrm{g} / \mathrm{ml}$ ) was added (Bures et al. 2003; Leong-Skornickova et al. 2007; Lysak et al. 2000; Palomino et al. 2003; Pecinka et al. 2006; Roux et al. 2003). All the sample preparation methods were done on ice. The fluorescence intensity of 5000 particles was recorded using a BD FACSAria III Cell Sorter (BD Biosciences, California, USA). Solanum lycopersicum L. Stupicke polni rane, Glycine max Merr. Polanka and Zea mays L. CE-777 were used as internal reference standards to determine the genome size of cardamom and Z. mays L. CE-777 was found to be appropriate reference standard there exist around a twofold variation between the mean peak intensity of the sample and the standard (Petr et al. 2012). Each sample was analysed twice for getting reliable results.

The number of nuclei and coefficient of variation $(\mathrm{CV})$ for peaks of both the cardamom and maize were procured by gating using the BD FACs Diva software. Rectangular gates were drawn manually around the section which is of interest on the histogram of PI fluorescenceArea against PI fluorescence-width to discard the intervention of debris. The mean peak intensity of nuclei of cardamom and maize in the G1 phase of the cell cycle were compared and 2C DNA content of cardamom was 
Table 1 Details of cardamom accessions used for genome size estimation and ISSR analysis

\begin{tabular}{|c|c|c|c|c|}
\hline Accession no. & Type/name & Location & Latitude & Longitude \\
\hline C11 & Palakkudi (LR) & Anakkuzhy, Idukki & N 09³7'31.09'" & $\mathrm{E} 77^{\circ} 06^{\prime} 07.08^{\prime \prime}$ \\
\hline C16 & Feral & Pandimotta & N $08^{\circ} 50^{\prime} 06.11^{\prime \prime}$ & $\mathrm{E} 77^{\circ} 11^{\prime} 03.00^{\prime \prime}$ \\
\hline $\mathrm{C} 17$ & Feral & Pandimotta & N $08^{\circ} 50^{\prime} 06.11^{\prime \prime}$ & $\mathrm{E} 77^{\circ} 11^{\prime} 03.0^{\prime \prime}$ \\
\hline C26 & Wild & Rosemala & $N 8^{\circ} 54^{\prime} 49.45^{\prime \prime}$ & $\mathrm{E} 77^{\circ} 10^{\prime} 55.45^{\prime \prime}$ \\
\hline C28 & Feral & Bonacaud & N $8^{\circ} 41^{\prime} 33.09^{\prime \prime}$ & $\mathrm{E} 77^{\circ} 10^{\prime} 45.09^{\prime \prime}$ \\
\hline C31 & Feral & Bonecadu & $\mathrm{N} 08^{\circ} 41^{\prime} 37.03^{\prime \prime}$ & $\mathrm{E} 77^{\circ} 10^{\prime} 48.03^{\prime \prime}$ \\
\hline C38 & Feral & Cheenikala, Sankili & NA & NA \\
\hline C39 & Feral & Cheenikala, Sankili & NA & NA \\
\hline C40 & Feral & Peppara & N $8^{\circ} 37^{\prime} 11.98^{\prime \prime}$ & $\mathrm{E} 77^{\circ} 11^{\prime} 47.87^{\prime \prime}$ \\
\hline C51 & Kanniyelam (Feral) & Maniyaramkudi, Idukki & N 9 $53^{\prime} 45.78^{\prime \prime}$ & $E 76^{\circ} 56^{\prime} 08.28^{\prime \prime}$ \\
\hline C52 & Feral & Agasthyamala & N $8^{\circ} 37^{\prime} 03.39^{\prime \prime}$ & $\mathrm{E} 77^{\circ} 13^{\prime} 45.56^{\prime \prime}$ \\
\hline C53 & Feral & Bonacaud & $N 8^{\circ} 41^{\prime} 52.01^{\prime \prime}$ & $E 77^{\circ} 10^{\prime} 53.0^{\prime \prime}$ \\
\hline C55 & Palakkudi (LR) & Idukki & N $9^{\circ} 41^{\prime} 04.0^{\prime \prime}$ & $\mathrm{E} 77^{\circ} 11^{\prime} 08.0^{\prime \prime}$ \\
\hline C61 & ICRI 2 (RV) & Idukki & NA & NA \\
\hline C62 & ICRI 5 (RV) & Idukki & NA & NA \\
\hline C63 & Valli Green Gold (LR) & Idukki & NA & NA \\
\hline C65 & PV2 (RV) & Idukki & N $09^{\circ} 47^{\prime} 48.0^{\prime \prime}$ & E $77^{\circ} 09^{\prime} 30.0^{\prime \prime}$ \\
\hline C68 & Wild & ICRI, Idukki & NA & NA \\
\hline $\mathrm{C} 70$ & Feral & Kakki, Periyar & N $9^{\circ} 18^{\prime} 55.08^{\prime \prime}$ & $E 77^{\circ} 8^{\prime} 34.08^{\prime \prime}$ \\
\hline C74 & Wild & Variyam, Ernakulam & N $10^{\circ} 12^{\prime} 57.01^{\prime \prime}$ & $E 76^{\circ} 51^{\prime} 26.08^{\prime \prime}$ \\
\hline C75 & Wild & Therakkudy, Ernakulam & N $10^{\circ} 13^{\prime} 13.20^{\prime \prime}$ & $E 76^{\circ} 47^{\prime} 03.07^{\prime \prime}$ \\
\hline C76 & Wild & Kulirukadu,A ryankavu & N $9^{\circ} 1^{\prime} 09.02^{\prime \prime}$ & $\mathrm{E} 77^{\circ} 6^{\prime} 08.00^{\prime \prime}$ \\
\hline C77 & Wild & Valiyathalappara, Aryankavu & $N 9^{\circ} 1^{\prime} 59.01^{\prime \prime}$ & $E 77^{\circ} 7^{\prime} 59.05^{\prime \prime}$ \\
\hline C81 & Feral & IISR IC-349337, Karnataka & NA & NA \\
\hline C83 & Feral & IISR IC-349396, Karnataka & NA & NA \\
\hline C84 & Feral & IISR IC-349399, Karnataka & NA & NA \\
\hline C86 & Feral & IISR IC-349436, Karnataka & NA & NA \\
\hline C91 & Feral & IISR IC 349459, Karnataka & NA & NA \\
\hline C96 & Avinash-1 (RV) & IISR, Karnataka & NA & NA \\
\hline C97 & Appangala-1 (RV) & IISR, Karnataka & NA & NA \\
\hline
\end{tabular}

$R V$ released variety, $L R$ landrace. Both $R V$ and $L R$ are treated as cultivars

estimated (Wang et al. 2015). The formula used to estimate the nuclear DNA content of cardamom (Gregory et al. 2015) was: 2C DNA nuclear content (pg) of cardamom $=($ sample peak mean/standard peak mean $) \times 2 \mathrm{C}$ DNA content of the reference standard (pg). One way ANOVA and $t$ Test were used to check the significance of genome size variation among the accessions $(\mathrm{n}=30)$ (Sheidai et al. 2014).

\section{Determination of chromosome count}

The root tips of cardamom were collected around 10.30 am which is the peak hour of mitotic activity in cardamom plants. Somatic chromosomes from root tip cells were fixed in Carnoy's fluid (ethanol and glacial acetic acid in the ratio $3: 1$ ). The root tips were pretreated in $0.002 \mathrm{M}$ solution of 8-hydroxyquinoline for $2 \mathrm{~h}$ at $4{ }^{\circ} \mathrm{C}$.
The smear and squash preparations were stained in $2 \%$ acetocarmine, and well spread chromosome preparations were photomicrographed using Leica DM 100 digital camera attached with Leica DM 2500 trinocular microscope (Ngamriabsakul 2004).

\section{ISSR analysis}

DNA was isolated from young leaf tissue of the samples using DNeasy Plant Mini Kit (Qiagen, Germany) following manufacturer's instructions. The concentration and quality of the isolated DNA were checked using Biophotometer (Eppendorf India Ltd), $0.8 \%$ agarose gel electrophoresis and was diluted to a final concentration of $50 \mathrm{ng} / \mu \mathrm{l}$. Polymerase chain reaction (PCR) was carried out on the plant samples each in $25 \mu \mathrm{l}$ reaction consisting of $50 \mathrm{ng}$ template DNA, $1 \times$ PCR buffer 
(Origin, Kerala), $200 \mu \mathrm{M}$ of each of the four dNTPs, $15 \mathrm{pM}$ primer and one unit of Taq DNA polymerase (Origin, Kerala). Thirty-six ISSR primers (IDT, New Delhi) were checked and evaluated for clarity, consistency and number of polymorphisms. Twenty-six primers which created clear bands and amplification profile were finally selected for the study (Table 2). Amplification was carried out with the following conditions: $2 \mathrm{~min}$ at $94{ }^{\circ} \mathrm{C}$, followed by 35 cycles of denaturation for $30 \mathrm{~s}$ at $94{ }^{\circ} \mathrm{C}$, annealing for $1 \mathrm{~min}$, extension for $2 \mathrm{~min}$ at $72{ }^{\circ} \mathrm{C}$, and for $7 \mathrm{~min}$ at $72{ }^{\circ} \mathrm{C}$ for the final extension using Agilent Sure Cycler (Agilent Technologies, Malaysia). The amplified products were resolved with the aid of $1.4 \%$ agarose gel electrophoresis in $1 \times \mathrm{TBE}$ buffer and visualized using Safe View ${ }^{\text {TM }}$ Classic (Applied Biological Materials, Canada) in gel documentation system (UVP, UK). $1 \mathrm{~kb}$ or $100 \mathrm{bp}$ DNA ladder (Origin, Kerala) was loaded in the gel as the size marker.

The bands obtained with each primer were scored as diallelic characters: 1 denotes present and 0 denotes

Table 2 Details of ISSR primers used to analyze genetic diversity in $\mathbf{3 0}$ cardamom accessions

\begin{tabular}{|c|c|c|c|}
\hline SI. no. & ISSR primer & Sequence & $\mathrm{Ta}\left({ }^{\circ} \mathrm{C}\right)$ \\
\hline 1 & 5807 & 5'-TATATATATATATATAC-3' & 50.0 \\
\hline 2 & 5809 & $5^{\prime}-A G A G A G A G A G A G A G A G C-3^{\prime}$ & 52.0 \\
\hline 3 & S811 & $5^{\prime}-$ GAGAGAGAGAGAGAGAT-3' & 50.4 \\
\hline 4 & 5813 & $5^{\prime}-$ GAGAGAGAGAGAGAGAC-3' & 52.0 \\
\hline 5 & S817 & $5^{\prime}-\mathrm{CACACACACACACACAT-3^{ \prime }}$ & 50.0 \\
\hline 6 & 5820 & $5^{\prime}-$ CACACACACACACACAA-3' & 50.0 \\
\hline 7 & S824 & 5'-ТСТСТСТСТСТСТСТСС-3' & 52.0 \\
\hline 8 & 5826 & 5'-TCTCTCTCTCTCTCTCG-3' & 52.0 \\
\hline 9 & S829 & $5^{\prime}-\mathrm{ACACACACACACACC}-3^{\prime}$ & 52.0 \\
\hline 10 & 5834 & $5^{\prime}$-TGTGTGTGTGTGTGC-3' & 52.0 \\
\hline 11 & S835 & $5^{\prime}$-AGAGAGAGAGAGAGAGYT-3' & 50.0 \\
\hline 12 & S836 & $5^{\prime}-A G A G A G A G A G A G A G A G Y C-3^{\prime}$ & 50.0 \\
\hline 13 & 5842 & $5^{\prime}-$ GAGAGAGAGAGAGAGAYC-3' & 53.7 \\
\hline 14 & S844 & 5'-CTCTCTCTCTCTCTCTRA-3' & 50.0 \\
\hline 15 & S845 & 5'-CTCTCTCTCTCTCTCTRC-3' & 53.0 \\
\hline 16 & S849 & $5^{\prime}$-CACACACACACACACARG-3' & 53.7 \\
\hline 17 & S850 & 5'-GTGTGTGTGTGTGTGTCA-3' & 53.7 \\
\hline 18 & S851 & 5'-GTGTGTGTGTGTGTGTTC-3' & 55.8 \\
\hline 19 & S855 & 5'-TCTCTCTCTCTCTCTCRG-3' & 51.0 \\
\hline 20 & S857 & $5^{\prime}-A C A C A C A C A C A C A C A C Y-3^{\prime}$ & 53.0 \\
\hline 21 & S860 & $5^{\prime}-\mathrm{ACACACACACACACACTG-3^{ \prime }}$ & 53.0 \\
\hline 22 & S864 & 5'-TGTGTGTGTGTGTGA-3' & 47.0 \\
\hline 23 & S868 & 5'-СТССТССТССТССТССТС-3' & 47.0 \\
\hline 24 & S872 & $5^{\prime}-$ GAAGAAGAAGAAGAAGA-3' & 40.0 \\
\hline 25 & S880 & 5'-СТTCACTTCACTTCA-3' & 51.0 \\
\hline 26 & $\mathrm{~S} 895$ & $5^{\prime}-G G A G A G G A G A G G A G A-3^{\prime}$ & 51.0 \\
\hline
\end{tabular}

absent (Lamyai et al. 2014; Mark et al. 2015). The amplified products extends in size from 200 to $2000 \mathrm{bp}$. A binary qualitative data matrix was formed and estimated the Observed number of alleles $(n a)$, Effective number of alleles (ne), Nei's gene diversity $(h)$, Shannon's Information index $(I)$ and number of polymorphic loci $(p)$ using the software POPGENE ver 1.31 (Yeh et al. 1999; Amit et al. 2014).

In an attempt to get a deeper understanding of the relationship between genetic variability and genome size, $2 \mathrm{C}$-values of the accessions which are common in the present study and that of our previous research (Anjali et al. 2015) were subjected to correlation analysis with ISSR and EST-SSR based genetic variability parameters such as number of alleles per loci and polymorphic alleles.

\section{Results}

$2 \mathrm{C}$ nuclear DNA content estimation

Flow cytometric study generated histograms with good resolution peaks (Fig. 1). Nuclear DNA content of thirty accessions of cardamom were estimated (Table 3). 2C DNA amount shows low variation among the studied accessions. Maximum genome size was $3.22 \mathrm{pg}$ shown in accession C61 (ICRI-2, a released variety) and minimum was found in C39 (a wild accession from Cheenikkala, Sankhili) as $2.57 \mathrm{pg}$. It shows a difference of about 1.25 times. ANOVA and $t$ Test analysis did not find out significant differences in nuclear DNA content among the 30 accessions analysed as wild, feral, and cultivar groups. Mean 2C nuclear DNA content of all the thirty accessions of cardamom was calculated as $2.87 \mathrm{pg}$ and the mean genome size is $2.81 \times 10^{9} \mathrm{bp}$. This is the first report on genome size of $E$. cardamomum.

\section{Chromosome count}

The chromosome number was found to be $2 n=48$ in the studied accessions by observing the mitotic metaphase stage. The experimental was repeated with different samples, but no variation in chromosome number was observed.

\section{Genetic diversity analysis using ISSR markers}

Twenty-six primers that generated polymorphic bands were used for genetic diversity analysis of the thirty accessions of cardamom (Table 4). Twenty-six primers generated 97 bands and polymorphism was shown by 85 bands $(87.63 \%)$. The number of polymorphic bands obtained for each primer extends from one (S849) to seven (S845). Shannon's Information Index (I) differ from 0.23 to 0.54 with an average of 0.37 . Among the thirty accessions of cardamom studied, C53 (feral from Bonacaud) showed a very prominent level of genetic diversity $(h=0.38$, 

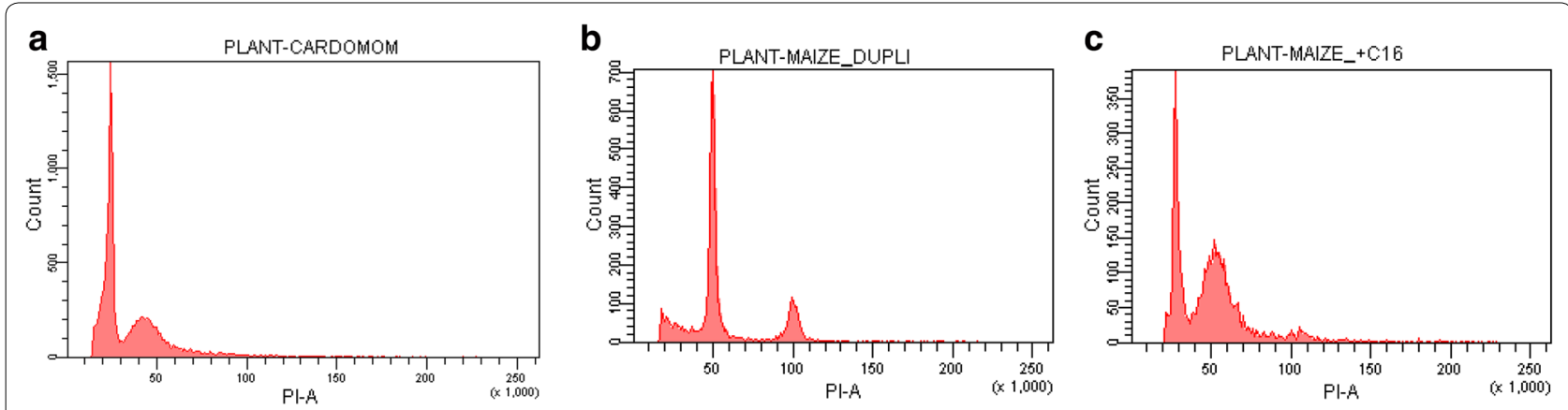

Fig. 1 Representative flow cytometric histograms (a) cardamom (sample) alone (b) Zea mays (internal reference standard) alone and (c) documenting both cardamom and Z. mays

Table 3 Genome size of the studied accessions categorized into various groups

\begin{tabular}{|c|c|c|c|}
\hline Acc. no. & Type & 2C DNA (pg) & Genome size (bp) \\
\hline $\mathrm{C} 11$ & $L R$ & 2.82 & $2.76 \times 10^{9}$ \\
\hline $\mathrm{C} 51$ & Feral & 2.71 & $2.65 \times 10^{9}$ \\
\hline C55 & $L R$ & 3.02 & $2.95 \times 10^{9}$ \\
\hline C61 & RV & 3.22 & $3.15 \times 10^{9}$ \\
\hline C62 & RV & 2.68 & $2.62 \times 10^{9}$ \\
\hline C63 & LR & 2.93 & $2.87 \times 10^{9}$ \\
\hline C65 & RV & 3.10 & $3.03 \times 10^{9}$ \\
\hline C96 & RV & 3.07 & $3.00 \times 10^{9}$ \\
\hline C97 & RV & 2.84 & $2.78 \times 10^{9}$ \\
\hline $\mathrm{C} 16$ & Feral & 2.83 & $2.77 \times 10^{9}$ \\
\hline $\mathrm{C} 17$ & Feral & 2.89 & $2.83 \times 10^{9}$ \\
\hline $\mathrm{C} 28$ & Feral & 2.96 & $2.89 \times 10^{9}$ \\
\hline C31 & Feral & 2.69 & $2.63 \times 10^{9}$ \\
\hline $\mathrm{C} 38$ & Feral & 2.78 & $2.72 \times 10^{9}$ \\
\hline C39 & Feral & 2.57 & $2.51 \times 10^{9}$ \\
\hline $\mathrm{C} 40$ & Feral & 2.77 & $2.71 \times 10^{9}$ \\
\hline C52 & Feral & 2.95 & $2.89 \times 10^{9}$ \\
\hline C53 & Feral & 2.72 & $2.66 \times 10^{9}$ \\
\hline $\mathrm{C} 70$ & Feral & 2.72 & $2.66 \times 10^{9}$ \\
\hline C81 & Feral & 3.04 & $2.97 \times 10^{9}$ \\
\hline C83 & Feral & 3.14 & $3.07 \times 10^{9}$ \\
\hline $\mathrm{C} 84$ & Feral & 2.75 & $2.69 \times 10^{9}$ \\
\hline C86 & Feral & 2.85 & $2.79 \times 10^{9}$ \\
\hline C91 & Feral & 2.74 & $2.68 \times 10^{9}$ \\
\hline $\mathrm{C} 26$ & Wild & 2.91 & $2.85 \times 10^{9}$ \\
\hline C68 & Wild & 3.14 & $3.07 \times 10^{9}$ \\
\hline $\mathrm{C} 74$ & Wild & 2.74 & $2.68 \times 10^{9}$ \\
\hline C75 & Wild & 2.70 & $2.64 \times 10^{9}$ \\
\hline $\mathrm{C} 76$ & Wild & 2.97 & $2.90 \times 10^{9}$ \\
\hline $\mathrm{C} 77$ & Wild & 2.86 & $2.80 \times 10^{9}$ \\
\hline
\end{tabular}

$R V$ released variety, $L R$ landrace

$I=0.54, P=80.77 \%)$ and was lowest $(h=0.16, I=0.23$, $P=38.46 \%$ ) for C96 (Avinash-I, a released variety from IISR).
Table 4 Genetic diversity indices of the thirty cardamom accessions studied using twenty-six ISSR primers

\begin{tabular}{|c|c|c|c|c|c|}
\hline Accessions & $n a$ & ne & $h$ & $I$ & $P(\%)$ \\
\hline $\mathrm{C} 40$ & 1.65 & 1.50 & 0.27 & 0.40 & 65.38 \\
\hline $\mathrm{C} 26$ & 1.62 & 1.49 & 0.26 & 0.38 & 61.54 \\
\hline $\mathrm{C} 75$ & 1.65 & 1.54 & 0.29 & 0.41 & 65.38 \\
\hline $\mathrm{C} 74$ & 1.69 & 1.57 & 0.30 & 0.43 & 69.23 \\
\hline C68 & 1.73 & 1.49 & 0.28 & 0.41 & 73.08 \\
\hline $\mathrm{C} 70$ & 1.69 & 1.54 & 0.30 & 0.43 & 69.23 \\
\hline C51 & 1.77 & 1.61 & 0.33 & 0.47 & 76.92 \\
\hline $\mathrm{C} 17$ & 1.73 & 1.64 & 0.34 & 0.48 & 73.08 \\
\hline C53 & 1.81 & 1.73 & 0.38 & 0.53 & 80.77 \\
\hline $\mathrm{C} 28$ & 1.65 & 1.58 & 0.31 & 0.43 & 65.38 \\
\hline C52 & 1.65 & 1.45 & 0.26 & 0.37 & 65.38 \\
\hline C38 & 1.50 & 1.40 & 0.21 & 0.31 & 50.00 \\
\hline C11 & 1.58 & 1.48 & 0.26 & 0.36 & 57.69 \\
\hline $\mathrm{C} 76$ & 1.62 & 1.50 & 0.27 & 0.39 & 61.54 \\
\hline $\mathrm{C} 77$ & 1.77 & 1.61 & 0.33 & 0.48 & 76.92 \\
\hline $\mathrm{C} 16$ & 1.61 & 1.53 & 0.28 & 0.40 & 61.54 \\
\hline $\mathrm{C} 63$ & 1.65 & 1.52 & 0.28 & 0.40 & 65.38 \\
\hline C31 & 1.58 & 1.47 & 0.25 & 0.36 & 57.69 \\
\hline C55 & 1.62 & 1.52 & 0.28 & 0.39 & 61.54 \\
\hline C61 & 1.54 & 1.38 & 0.21 & 0.31 & 53.85 \\
\hline C62 & 1.58 & 1.39 & 0.22 & 0.33 & 57.69 \\
\hline C65 & 1.58 & 1.46 & 0.25 & 0.35 & 57.69 \\
\hline C39 & 1.46 & 1.33 & 0.19 & 0.27 & 46.15 \\
\hline C91 & 1.38 & 1.34 & 0.18 & 0.25 & 38.46 \\
\hline C97 & 1.42 & 1.35 & 0.19 & 0.27 & 42.31 \\
\hline C96 & 1.38 & 1.30 & 0.16 & 0.23 & 38.46 \\
\hline $\mathrm{C} 81$ & 1.58 & 1.48 & 0.25 & 0.36 & 57.69 \\
\hline C84 & 1.46 & 1.36 & 0.19 & 0.28 & 46.15 \\
\hline C83 & 1.54 & 1.44 & 0.23 & 0.33 & 53.85 \\
\hline C86 & 1.54 & 1.40 & 0.22 & 0.32 & 53.85 \\
\hline Mean & 1.60 & 1.48 & 0.26 & 0.37 & 60.12 \\
\hline SD & 0.11 & 0.10 & 0.05 & 0.07 & 10.85 \\
\hline
\end{tabular}

$n a=$ observed number of alleles, $n e=$ effective number of alleles, $h=$ Nei's gene diversity, I = Shannon's information index, $P(\%)=$ percentage of polymorphic loci 
Correlation between genome size and genetic variability The analysis revealed no correlation between the genetic variability and genome size in the studied accessions (Fig. 2). Further, the thirty accessions were divided into four groups based on their wild/cultivar nature. The oneway ANOVA was estimated from these four groups, viz. feral $[\mathrm{n}=16$, mean $(\mathrm{m})=2.82$, variance $(\mathrm{v})=0.0213]$, landrace $(\mathrm{n}=3, \mathrm{~m}=2.92, \mathrm{v}=0.0100)$, released varieties $(\mathrm{n}=5, \mathrm{~m}=2.98, \mathrm{v}=0.0474)$, and wild $(\mathrm{n}=6, \mathrm{~m}=2.87$, $\mathrm{v}=0.0257)$. Since if $\mathrm{F}(1.4992)<\mathrm{F}(2.9752)$ crit, it was concluded that the four groups did not differ significantly from each other. Further $t$ Tests were also performed to test each of the above pairs of the means. These tests also did not show any significant differences between any of the pairs.

\section{Discussion}

It is obvious that different individuals of same species vary in genome composition due to various evolutionary reasons. Cardamom is one of the species domesticated since modern man started agricultural practices and with a strong desire to satisfy his appetite. Mentions of cardamom are available in old Indian literature written somewhere in 3000 BC (Ravindran and Madhusoodanan 2003). Cardamom cultivation has started in late nineteenth century. Since then, the natural populations of cardamom are slowly replaced by 'selections' which narrow down the genetic base and thus the evolutionary potential of cardamom. Some of the remaining of the natural populations of cardamom available in the pristine forest areas of Kerala were collected for this study and analysed along with other available genotypes (Table 1). The

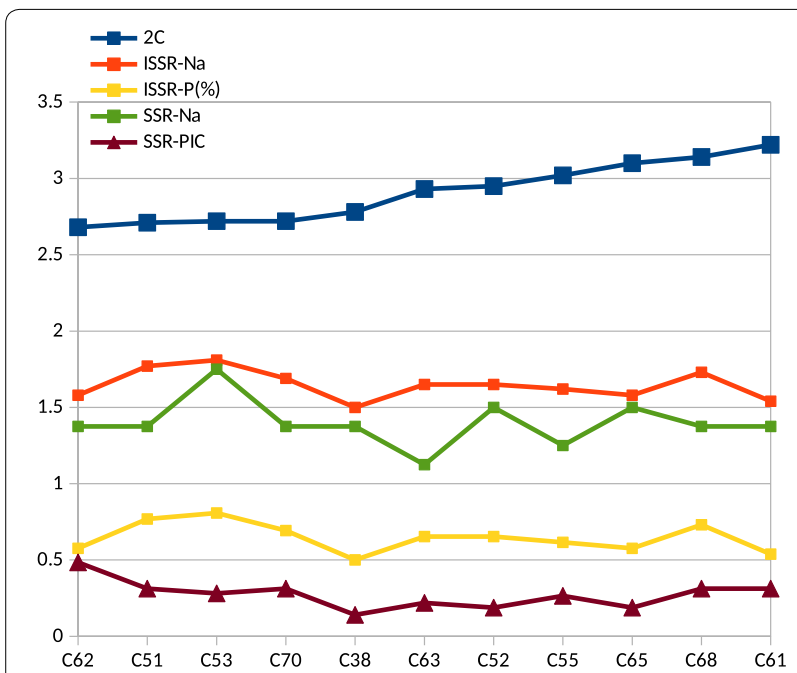

Fig. 2 Relationship between 2C-value, ISSR and EST-SSR variability. Na stands for number of alleles per locus, $P$ for percentage of polymorphic loci and PIC for Polymorphic Information Content present study revealed that the distribution of the genetic diversity and differences in genome size in various accessions are highly randomized having no correlation with the type of the genotype (viz. wild, feral, released variety or cultivar).

Domestication generally leads to changes in many productive traits in crop species when compared to their wild progenitors (Colunga-Garcia et al. 1996; ColungaGarcia and May-Pat 1997; Casas et al. 1999, 2007). In cardamom, domestication has increased the number of branches and the number of inflorescences per clump, which have resulted in a significant increase in the total number of flowers per clump. These features have obviously resulted in a significant increase in fruit yield in the cultivars (Kuriakose et al. 2008). Considerable variation occurs in cardamom, because it is cross-pollinated (Wardini and Thomas 1999). Studies show that there was no reproductive barrier between wild and cultivated cardamom populations (Kuriakose et al. 2008). Fruits with viable seeds were produced when the accessions used for the present study were subjected to manual cross pollination each other (Sabu and Shefeek, unpublished).

\section{Genome size estimation}

Variation in nuclear DNA content was observed among the studied accessions of cardamom which ranged from 2.54 to $3.22 \mathrm{pg}$. However, this variation was not statistically significant as estimated using one-way ANOVA and $t$ Test. This means that genome size estimates among the 30 accessions or among the various groups (wild, feral, released variety and cultivar) did not differ significantly from each other. According to various reports, intraspecific variation in nuclear DNA content of plants is a disputable subject in the scientific community. Very few studies are reported with remarkable level of intraspecific genome size variation (Bennett and Leitch 2005). As per some of the earlier studies on Collinsia verna, Pisum sativum and Glycine max, it was observed that there was a significant variation. But later Greilhuber (1998) came out with the conclusion that they were merely due to some technical issues. Based on some works which described the variation in genome size within species using authentic controls and standards, Murray (2005) explained that this intraspecific variation has some taxonomic relevance if the former could be related to morphological variation. About 1.19 times variation in genome size was reported for Linum glaucum populations in Iran and difference in nuclear DNA content was found to be associated with altitude and morphological characters (Seyed et al. 2015). Marek et al. (2009) reported a high level intraspecific variation in different populations of Picris hieracioides. Significant level of intraspecific variation was noted in five species of 
Lathyrus genus (Nandini et al. 1997). The contradiction of having low intraspecific variation and high interspecific variation in diploid Triticeae species proposed that emergence of genome size occurs just before, during or right after the process of speciation (Eilam et al. 2007). 2C nuclear DNA content analysis exhibited a 1.1 fold difference and thus a low level intraspecific variation in Camellia sinesnsis var. assamica (Huang et al. 2013). 1C nuclear DNA content of the populations of Pinus nigra was reported to have around $23 \mathrm{pg}$ (Faruk et al. 2007). Sandra et al. (2015) described that DNA content shows only a small variation within Miscanthus sinensis cultivars. Considerable differences in DNA content was not observed among the five populations of Pinus heldreichii when a $t$ Test was performed (Bogunic et al. 2003).

\section{Genome size in Zingiberaceae members}

A search in the C-value database of RBG Kew using the term 'Zingiberaceae' resulted in 39 records belonging to 7 genus such as Curcuma, Paracautleya, Hitchenia, Kaempferia, Stahlianthus, Alpinia and Zingiber. Average $2 \mathrm{C}$ value of the family is $2.79 \mathrm{pg}$ and the minimum and maximum values are 1.66 and 12.05 respectively. The mean $2 \mathrm{C}$ value of cardamom estimated in the present study was $2.87 \mathrm{pg}$ which falls in comparable range of the family.

\section{Use of genome size estimation}

In addition to chromosome numbers and ploidy levels, genome size has been estimated in many plants as it is an important attribute in biology and biodiversity (Bennett et al. 2000; Hanson et al. 2001) and pre-requisite for genome sequencing experiments. The co-processed samples with different genome sizes always gave two distinct peaks, which is the most convincing evidence for genuine differences in DNA content (Greilhuber 2005). Genome size variation has significant consequences at cellular, tissue and organismal levels and also influences phenological and ecological behaviour. Comparisons of genome size data within genus and species levels and probable phylogenetic relationships suggest that both increases and decreases of genome size have occurred in evolution (Wendel et al. 2002; Soltis et al. 2003).

\section{Ploidy level and genome size}

The occurrence of different chromosome numbers $(2 \mathrm{n}=48,52)$ in cardamom was reported in early cytological studies (Gregory 1936; Sharma and Bhattacharya 1959; Chakravarti 1948). Variations in chromosome numbers were observed in Mysore and Malabar varieties of cardamom indicted that aneuploidy as well as structural alterations in the chromosome have contributed to the varietal differentiation (Chandrasekhar and
Sampathkumar 1986). Earlier workers have reported that cardamom is of amphidiploid origin from wild species (Peter et al. 2007). As ploidy level is well correlated with the mode of reproduction, detailed knowledge of genome size in particular species plays an important role in forming hypotheses about evolutionary potential of the species and evolutionary processes in the genus (Chrtek et al. 2007). The present study did not find any ploidy changes among the studied accessions as evident from observations based on cytology and the present flow cytometry analyses. In general, ploidy screening can be done through analysing a test sample with those of the same species having known ploidy using the same instrument settings. This would result in a histogram from which ploidy can be determined from the G1 peak position. The wild cardamom plant collected from Therakkudy, Ernakulam (C75) was screened for chromosome number by root tip squash technique and found to be tetraploid $(2 \mathrm{n}=4 \mathrm{x}=48)$. While calculating the $2 \mathrm{C}$ DNA content of cardamom using maize as internal reference standard, the G1 peak of all the cardamom accessions were positioned around channel 26 . So it can be concluded that all the 30 accessions of cardamom that were taken for this particular study are having tetraploid nature.

\section{Genome size and genetic variability}

It is well cited that there is no correlation between the amount of DNA per cell and organismal advancement or genetic complexity (Sparrow et al. 1972; Price 1988) which has been historically termed the " $\mathrm{C}$-value paradox" (Thomas 1971). Since the discovery of non-coding DNA and its impact on genome size variation [for example, retrotransposons have increased the size of the maize genome two- to five-fold since the divergence of maize and sorghum from a common ancestor about 16 million years ago (Sanmiguel and Bennetzen 1998)], "paradox" has been replaced by "enigma" in order to address the matter properly (Gregory 2002, 2004). It is now generally agreed that the $\mathrm{C}$-value enigma is due to the differential amplification and proliferation of the repetitive sequences of the genome among organisms (Bennetzen 2000, 2002; Kidwell 2002; Hawkins et al. 2006).

Microsatellites are ubiquitous class of simple repetitive DNA sequences which are abundant in all eukaryotes analyzed and is thought to result from the mutational effects of replication slippage (Tautz and Schlötterer 1994). To find out the relation between genome size and microsatellite occurrence, the microsatellite frequency was analyzed in plant species with a 50-fold range in genome size that is mostly attributable to the recent amplification of repetitive DNA (San Miguel et al. 1998). It was found that the overall frequency of microsatellites was inversely related to genome size and to the 
proportion of repetitive DNA but remained constant in the transcribed portion of the genome among species (Morgante et al. 2002). This indicates that most microsatellites reside in regions pre-dating the recent genome expansion in many plants. The microsatellite frequency was higher in transcribed regions, especially in the untranslated portions, than in genomic DNA (Morgante et al. 2002). In a more recent study, it was found that EST-SSR density in the coding regions was not associated with genome size in selected genera of woody trees representing gymnosperms (17 species from seven genera) and angiosperms (40 species from eight genera) (Ranade et al. 2014).

In the present study, high genetic variation was observed among different accessions of cardamom using ISSR markers (for example, Shannon's information index (Table 4) ranged from 0.23 to 0.53 , around $130 \%$ increase). Similarly, the variability in genome size was also clearly observed. However, there was no correlation between the increase in the genetic variability parameters and genome size in the studied accessions (Fig. 2) which is at par with a previous finding that EST-SSR density was not associated with genome size in neither angiosperms nor gymnosperms (Ranade et al. 2014).

\section{Conclusion}

The present study focuses on intraspecific variation in cardamom with respect to genome size and ISSR data. Variability in genome size was found for different categories of cardamom like wild, feral and cultivar types. Genetic variability was analyzed among the thirty accessions using twenty-six ISSR primers. None of the genetic variability parameters showed a correlation with genome size. It could be concluded that the genetic variability exhibited by the different accessions of cardamom occurs due to minor insertion or deletion of nucleotide sequences. It might be reasonable to assume that retrotransposons that make up the majority of the plant genomes (San Miguel et al. 1998) could be attributable to the increased genome size in some of the cardamom genotypes.

\section{Authors' contributions}

NA carried out the flow cytometry and mitotic chromosome counting and drafted the manuscript. KMG carried out the molecular marker analysis. FN prepared the nuclei for flow cytometry and participated in the mitotic analysis. SS collected the germplasm and developed the ex situ conservatory. KKS designed and coordinated the study and helped to draft the manuscript. All authors read and approved the final manuscript.

\section{Acknowledgements}

Authors acknowledge Kerala State Council for Science, Technology and Environment (KSCSTE) for awarding fellowship for first and second authors and Director, JNTBGRI for providing necessary facilities and funding through plan project (P-114). We extend our sincere thanks to Director and staff of Indian Cardamom Research Institute (ICRI), Myladumpara, Idukki; Head and staff, Cardamom Research Station (CRC), Kerala Agricultural University, Pampadumpara, Idukki for providing cardamom germplasm and Mr. Chandran (Maniyarankudi, Idukki) and Mr. Sureshkumar (Ramakkalmedu) providing necessary help during our field trips for germplasm collection. We acknowledge Prof. Jaroslav Dolezel, Scientific Director, Centre of the Region Haná for Biotechnological and Agricultural Research, Institute of Experimental Botany, Czech Republic for providing seeds used as reference standards for the flow cytometry analysis. The authors express their gratitude to Director, Rajiv Gandhi Centre for Biotechnology (RGCB) for granting permission to conduct the flow cytometric analysis. We also thank Indu Ramachandran (RGCB) for her assistance with the flow cytometry work. We are indebted to Mr. Shafeek $\mathrm{S}$ and Ms. Jero Mathu (JNTBGRI) for collection and management of the cardamom germplasm and cytological observations respectively.

\section{Competing interests}

The authors declare that they have no competing interests.

Received: 24 February 2016 Accepted: 6 September 2016 Published online: 13 September 2016

\section{References}

Amit K, Priyanka M, Subhash CS, Velusamy S (2014) Efficiency of ISSR and RAPD markers in genetic divergence analysis and conservation management of Justicia adhatoda L., a medicinal plant. Plant Syst Evol 300:1409-1420

Anjali N, Sowmya SD, Nadiya F, Sabu KK (2015) Development of EST-SSR markers to assess genetic diversity in Elettaria cardamomum Maton. Int J Appl Sci Biotechnol 3(2):188-192

Arif M, Zaidi NW, Singh YP, Haq QMR, Singh US (2009) A comparative analysis of ISSR and RAPD markers for study of genetic diversity in Shisham (Dalbergia sissoo). Plant Mol Biol Rep 27:488-495

Aziza S, El-Kholy MS, Ebrahem ME (2015) Genetic diversity of Lemna gibba L. and L. minor L. populations in Nile delta based on biochemical and ISSR markers. Egypt J Exp Biol (Bot) 11(1):11-19

Bennett MD, Leitch IJ (2005) Plant genome size research: a field in focus. Ann Bot 95:1-6

Bennett MD, Bhandol P, Leitch IJ (2000) Nuclear DNA amounts in angiosperms and their modern uses-807 new estimates. Ann Bot 86:859-909

Bennetzen JL (2000) Transposable element contributions to plant gene and genome evolution. Plant Mol Biol 42:251-269

Bennetzen JL (2002) Mechanisms and rates of genome expansion and contraction in flowering plants. Genetica 115:29-36

Bogunic F, Muratovic E, Brown SC, Siljak-Yakovlev S (2003) Genome size and base composition of five Pinus species from the Balkan region. Plant Cell Rep 22:59-63

Bures P, Tichy L, Wang Y, Bartos J (2003) Occurrence of Polypodium mantoniae and new localities for P. interjectum in the Czech Republic confirmed using flow cytometry. Preslia 75:293-310

Cardle L, Ramsay L, Milbourne D, Macaulay D, Marshall D, Waugh R (2000) Computational and experimental characterization of physically clustered simple sequence repeats in plants. Genetics 156:847-854

Casas A, Valiente-Banuet A, Rojas-Martinez A, Davila P (1999) Reproductive biology and the process of domestication of the columnar cactus Stenocereus stellatus in central Mexico. Am J Bot 86:534-542

Casas A, Otero-Arnaiz A, Perez-Negron E, Valiente-Banuet A (2007) In situ management and domestication of plants in Mesoamerica. Ann Bot 100:1101-1115

Chakravarti AK (1948) Multiplication of chromosome numbers in relation to speciation in Zingiberaceae. Sci Cult 14:137-140

Chandrasekhar R, Sampathkumar K (1986) Karyological highlights on two cultivars of cardamom (Elettaria cardamomum Maton). J Cytol Genet 21:90-97

Chen JM, Gituru WR, Wang YH, Wang QF (2006) The extent of clonality and genetic diversity in the rare Caldesia grandis (Alismataceae): comparative results for RAPD and ISSR markers. Aquat Bot 84:301-307

Chen SC, Cannon CH, Shian KC, Liu JJ, Galbraith DW (2014) Genome size variation in the Fagaceae and its implications for trees. Tree Genet Genomes 10(4):977-988 
Chrtek J, Mraz P, Zahradnieek J, Mateo G, Szel Z (2007) Chromosome numbers and DNA ploidy levels of selected species of Hieracium S.Str. (Asteraceae). Folia Geobot 42:411-430

Colunga-Garcia MP, May-Pat F (1997) Morphological variation of henequen (Agave fourcroydes, Agavaceae) germplasm and its wild ancestor (A. angustifolia) under uniform growth conditions: diversity and domestication. Am J Bot 84:1449-1465

Colunga-Garcia MP, Estrada-Loera E, May-Pat F (1996) Patterns of morphological variation, diversity, and domestication of wild and cultivated populations of Agave in Yacatan, Mexico. Am J Bot 83:1069-1082

Dolezel J, Bartos J (2005) Plant DNA flow cytometry and estimation of nuclear genome size. Ann Bot 95:99-110

Dolezel J, Bartos J, Voglmayr H, Greilhuber J (2003) Nuclear DNA content and genome size of trout and human. Cytometry 51A:127-128

Dolezel J, Greilhuber J, Suda J (2007) Estimation of nuclear DNA content in plants using flow cytometry. Nat Protoc 2:2233-2243

Echt CS et al (2011) An annotated genetic map of loblolly pine based on microsatellite and CDNA markers. BMC Genet 12:17

Eilam T, Anikster Y, Millet E, Manisterski J, Sagi-Assif O, Feldman M (2007) Genome size and genome evolution in diploid Triticeae species. Genome 50(11):1029-1037

Elliott TA, Gregory TR (2015) What's in a genome? The C-value enigma and the evolution of eukaryotic genome content. Philos Trans R Soc B. doi:10.1098/rstb.2014.0331

Ellis JR, Burke JM (2007) EST-SSRs as a resource for population genetic analyses. Heredity 99:125-132

Faruk B, Edina M, Dalibor B, Sonja SY, Spencer B (2007) Genome size stability among five subspecies of Pinus nigra Arnold s.l. Environ Exp Bot 59:354-360

Galbraith DW (2010) Flow cytometry and fluorescence-activated cell sorting in plants: the past, present, and future. Biomedica 30(Suppl):65-70

Govindaraj M, Vetriventhan M, Srinivasan M (2015) Importance of genetic diversity assessment in crop plants and its recent advances: an overview of its analytical perspectives. Genet Res Int. Article ID 431487

Gregory PJ (1936) The floral morphology and cytology of Elettaria cardamomum Maton. J Linn Soc (Lond) 50:363-393

Gregory TR (2002) A bird's eye view of the C-value enigma: genome size, cell size, and metabolic rate in the class Aves. Evol Int J Org Evol 56:121-130

Gregory TR (2004) Macroevolution, hierarchy theory, and the C-value enigma. Paleobiology 30:179-202

Gregory JJ, Raymond JC, Anthony K, Aina P, Timothy JB (2015) Environmental adaptation in stomatal size independent of the effects of genome size. New Phytol 205:608-617. doi:10.1111/nph.13076

Greilhuber J (1998) Intraspecific variation in genome size: a critical reassessment. Ann Bot 82(Suppl. A):27-35

Greilhuber J (2005) Intraspecific variation in genome size in angiosperms: identifying its existence. Ann Bot 95:91-98

Hanson L, Mc Mahon KA, Johnson MAT, Bennett MD (2001) First nuclear DNA C-values for 25 angiosperm families. Ann Bot 87:251-258

Hawkins JS, Kim H, Nason JD, Wing RA, Wendel JF (2006) Differential lineage-specific amplification of transposable elements is responsible for genome size variation in Gossypium. Genome Res 16:1252-1261. doi:10.1101/gr.5282906

Huang H, Tong Y, Zhang Q-J, Gao L-Z (2013) Genome size variation among and within camellia species by using flow cytometric analysis. PLoS ONE 8(5):e64981. doi:10.1371/journal.pone.0064981

Kalia RK, Rai MK, Kalia S, Singh R, Dhawan AK (2011) Microsatellite markers: an overview of the recent progress in plants. Euphytica 177:309-334

Kidwell MG (2002) Tranposable elements and the evolution of genome size in eukaryotes. Genetica 115:49-63

Kumar N, Md JBM, Khader A, Rangaswami P, Irulappan (1997) Introduction to spices, plantation crops, medicinal and aromatic plants, 2.12-2.22. Oxford and IBH, New Delhi

Kumar PK, Radhakrishnan W, Hrideek TK, Sunil S, Kuruvilla KM, Sudharshan MR (2015) Shade trees and forage behaviour of honey bees in cardamom plantations. In: Mohanan et al (eds) Prospects in forestry and agriculture. Kerala Forest Research Institute KFRI, Peechi, India, pp 112-117

Kuriakose G, Sinu PA, Shivanna KR (2008) Domestication of cardamom (Elettaria cardamomum) in Western Ghats, India: divergence in productive traits and a shift in major pollinators. Ann Bot 103:727-733
Lamyai N, Runglawan S, Arunrat C (2014) Assessment of genotoxicity through ISSR Marker in Pistia stratiotes induced by lead. Environ Asia 7(2):99-107

Leong-Skornickova J, Sida O, Jarolimova V, Sabu M, Fer T, Travnicek P, Suda J (2007) Chromosome numbers and genome size variation in Indian species of Curcuma (Zingiberaceae). Ann Bot 100:505-526

Li YC, Korol AB, Fahima T, Nevo E (2004) Microsatellites within genes: structure, function, and evolution. Mol Biol Evol 21:991-1007

Loureiro J, Travnicek P, Rauchova J, Urfus T, Vit P, Stech M, Castro S, Suda J (2010) The use of flow cytometry in the biosystematics, ecology and population biology of homoploid plants. Preslia 82:3-21

Lysak MA, Rostkova A, Dixon JM, Rossi G, Dolezel J (2000) Limited Genome size variation in Sesleria albicans. Ann Bot 86:399-403

Marek S, Petr V, Tomas U, Jan S (2009) Complex pattern of genome size variation in a polymorphic member of the Asteraceae. J Biogeogr 36:372-384

Mark IS, Andrew CC, Fiona MC, Mary G, Chrissen ECG (2015) Are current ecological restoration practices capturing natural levels of genetic diversity? A New Zealand case study using AFLP and ISSR data from mahoe (Melicytus ramiflorus). NZ J Ecol 39(2):190-197

Michael TP (2014) Plant genome size variation: bloating and purging DNA. Brief Funct Genom 13(4):308-317

Milene MPF, Carlos RC, Wellington RC, Cosme DC (2011) Revisiting the DNA $\mathrm{C}$-values of the genome size-standards used in plant flow cytometry to choose the "best primary standards". Plant Cell Rep 30(7):1183-1191

Mohammad RM, Mohammad RFM, Ali E, Darab Y (2015) Genetic relationships of Iranian Hypericum perforatum L. wild populations as evaluated by ISSR markers. Plant Syst Evol 301(2):657-665

Morgante M, Hanafey M, Powell W (2002) Microsatellites are preferentially associated with nonrepetitive DNA in plant genomes. Nat Genet 30:194-200. doi:10.1038/ng822

Murray BG (2005) When does intraspecific C-value variation become taxonomically significant? Ann Bot 95:119-125

Nandini AV, Murray BG, Obrien IEW, Hammett KRW (1997) Intra- and interspecific variation in genome size in Lathyrus (Leguminosae). Bot J Linn Soc 125:359-366

Ngamriabsakul C (2004) A Chromosomal Study of Roscoea and Cautleya (Zingiberaceae): phylogenetic implications. Walailak J Sci Technol 1:70-86

Nitasha Bhat GM, Nayak N, Vinodraj K, Chandralekha N, Mathai P, Cherian $J$ (2015) Comparison of the efficacy of cardamom (Elettaria cardamomum) with pioglitazone on dexamethasone-induced hepatic steatosis, dyslipidemia, and hyperglycemia in albino rats. J Adv Pharm Technol Res 6(3):136

Oliveira-Miranda MA, Martino AM, De Oliveira-Miranda RM, BalboaK AM (2013) Conserving the genetic diversity of plants in Austral and Neotropical America (ANA): a metanalysis of published studies using samples of the region. Bot Rev. doi:10.1007/s12229-013-9128-5

Otto F (1990) DAPI staining of fixed cells for high-resolution flow cytometry of nuclear DNA. Methods Cell Biol 33:105-110

Padmesh PP, Sajan JS, Manikantan KM, Jayakumar KS, Subramoniam A (2012) ISSR analysis reveals high intraspecific variation in Rauvolfia serpentina L. - a high value medicinal plant. Biochem Syst Ecol 40:192-197

Palomino G, Dolezel J, Mendez I, Rubluo A (2003) Nuclear genome size analysis of Agave tequilana Weber. Caryologia 56:37-46

Pecinka A, Suchankova P, Lysak MA, Travnicek B, Dolezel J (2006) Nuclear DNA content variation among Central European Koeleria taxa. Ann Bot 98:117-122

Pellicer J, Leitch IJ (2014) The application of flow cytometry for estimating genome size and ploidy level in plants. Mol Plant Taxon Methods Protoc Methods Mol Biol. doi:10.1007/978-1-62703-767-9_14

Peter KV, Ravindran PN, Babu KN, Divakaran M (2007) Horticulture: breeding of spice crops (black pepper, cardamom, ginger and turmeric). In: Vegetable science (vegetables, tubers and spice crops). http://nsdl.niscair.res.in/ jspui/bitstream/123456789/471/1/revised\%20Breeding\%20of\%20spices. pdf. Accessed on 15 Nov 2015

Petr S, Petr B, Jakub S, Lucie H (2012) Measurements of genomic GC content in plant genomes with flow cytometry: a test for reliability. New Phytol 193:513-521. doi:10.1111/j.1469-8137.2011.03942.x

Prakashkumar R, Anoop KP, Ansari R, Sivu AR, Pradeep NS, Madhusoodanan PV (2015) Analysis of genetic diversity of Lagenandra spp. (Araceae) of Kerala (South India) using ISSR Markers. Int J Sci Res 4(6):775-777. ISSN No. $2277-8179$ 
Price HJ (1988) Nuclear DNA content variation within angiosperm species. Evol Trends Plants 2:53-60

Purseglove JW, Brown EG, Green CL, Robbins SRJ (1981) Spices. Longman, New York

Ranade SS, Lin YC, Zuccolo A, de Peer YV, García-Gil MR (2014) Comparative in silico analysis of EST-SSRs in angiosperm and gymnosperm tree genera. BMC Plant Biol 14:220. doi:10.1186/s12870-014-0220-8

Rao MN, Soneji JR, Chen CX, Huang S, Gmitter FG (2008) Characterization of zygotic and nucellar seedlings from sour orange-like citrus rootstock candidates using RAPD and EST-SSR markers. Tree Genet Genomes 4:113-124

Ravindran PN, Madhusoodanan KJ (2003) Cardamom: the genus Elettaria. Taylor and Francis, London

Roux N, Toloza A, Radecki Z, Zapata-Arias FJ, Dolezel J (2003) Rapid detection of aneuploidy in Musa using flow cytometry. Plant Cell Rep 21:483-490

Sakurako U, Hiroshi I, Nobuko O, Hisako O, Ohtsubo E, Fukui K (1997) Repetitive sequences: cause for variation in genome size and chromosome morphology in the genus Oryza. Plant Mol Biol 35:791-799

Samir Q, Sasikumar D, Moez AF (2015) Chemopreventive effect of cardamom (Elettaria cardamomum L.) against benzo(a)pyrene-induced forestomach papillomagenesis in Swiss Albino Mice. J Environ Pathol Toxicol Oncol 34(2):95-104

San Miguel P, Gaut BS, Tikhonov A, Nakajima Y, Bennetzen JL (1998) The paleontology of intergene retrotransposons of maize. Nat Genet 20:43-45. doi:10.1038/1695

Sandra C, Maria G, Monika R (2015) Miscanthus: inter- and intraspecific genome size variation among $m$. $\times$ giganteus, $m$. sinensis, $m$. sacchariflorus accessions. Acta Biol Crac Ser Bot 57(1):1-10

Sanmiguel P, Bennetzen JL (1998) Evidence that a recent increase in maize genome size was caused by the massive amplification of intergene retrotransposons. Ann Bot 82(Supplement A):37-44. Article No. bo980746

Sergio JO (2006) Flow cytometry (ploidy determination, cell cycle analysis, DNA content per nucleus). In: Mathesius U, Journet EP, Sumner LW (eds) The Medicago truncatula handbook. The Samuel Roberts Noble Foundation, Ardmore, United States. ISBN 0-9754303-1-9. http://www.noble.org/ Global/medicagohandbook/pdf/MedicagoHandbookv13.pdf. Accessed 20 Feb 2016

Sergio JO (2008) Flow cytometry in plant breeding. Cytom Part A 73A:581-598

Seyed MT, Masoud S, Morteza A, Fariba S, Zahra N (2015) Infraspecific morphological and genome size variations in Linum glaucum in Iran. Bio Divers 16(1):69-78. ISSN 1412-033X

Sharma AK, Bhattacharya YR (1959) Chromosome studies on two genera of the family Piperaceae. Genetics 29:256-289
Sheidai M, Yari R, Farahani F, Noormohammadi Z (2014) Evaluation of genetic diversity in cultivated (O. europaea subsp. europaea L. ssp. europea var. europaea) and wild olives (Olea cuspidata Wall) using genome size and RAPD markers. Nucleus 57(3):215-222

Soltis DE, Soltis PS, Bennett MD, Leitch IJ (2003) Evolution of genome size in the angiosperms. Am J Bot 90:1596-1603

Sparrow AH, Price HJ, Underbrink AG (1972) A survey of DNA content per cell and per chromosome of prokaryotic and eukaryotic organisms: some evolutionary considerations. Brookhaven Symp Biol 23:451-494

Suda J, Krahulcova A, Travnicek P, Rosenbaumova R, Peckert T, Krahulec F (2007) Genome size variation and species relationships in Hieracium sub-genus Pilosella (Asteraceae) as inferred by flow cytometry. Ann Bot 100:1323-1335

Tautz D, Schlötterer C (1994) Simple sequences. Curr Opin Genet Dev 4(6):832-837. doi:10.1016/0959-437X(94)90067-1

Temnykh S et al (2001) Computational and experimental analysis of microsatellites in rice (Oryza sativa L.): frequency, length variation, transposon associations, and genetic marker potential. Genome Res 11:1441-1452

Thomas CA (1971) The genetic organisation of chromosomes. Annu Rev Genet 5:237-256

Venugopal MN (1999) Natural disease escapes as sources of resistance against cardamom mosaic virus causing katte disease of cardamom (Elettaria cardamomum Maton). J Spices Aromat Crops 8:145-151

Wang J, Liu J, Kang M (2015) Quantitative testing of the methodology for genome size estimation in plants using flow cytometry: a case study of the Primulina genus. Front Plant Sci 6:354. doi:10.3389/fpls.2015.00354

Wardini TH, Thomas A (1999) Elettaria cardamomum (L.) Maton. In: Guzman CC, Siemonsma JE (eds) Plant resources of South-East Asia, No. 13. Spices. Backhuys, Leiden, pp 116-120

Wendel JF, Cronn RC, Johnston JS, Price HJ (2002) Feast and famine in plant genomes. Genetica 115:37-47

Xinye Z, Congwen S, Yadong Z, Yanling Y, Minren H (2009) Development of EST-SSR in Populus deltoides and P. euramericana. Sci Silvae Sin 45:53-59

Yeh FC, Yang RC, Boyle TBJ, Ye ZH, Mao JX (1999) POPGENE 3.2, user-friendly shareware for population genetic analysis. http://www.ualberta.ca/ fyeh

Yue-ping M, Jiang-xue W, Zhi-yang Y, Bing Q, Si-lan D (2015) Characterization of ploidy levels in Chrysanthemum L. by flow cytometry. J For Res 26(3):771-775

Zhiqiang M, Md AK, Weimin Z, Junjiang F (2014) DNA fingerprints of living fossil Ginkgo biloba by using ISSR and improved RAPD analysis. Biochem Syst Ecol 57:332-337

\section{Submit your manuscript to a SpringerOpen ${ }^{\circ}$ journal and benefit from:}

- Convenient online submission

- Rigorous peer review

- Immediate publication on acceptance

- Open access: articles freely available online

- High visibility within the field

- Retaining the copyright to your article

Submit your next manuscript at $\boldsymbol{\nabla}$ springeropen.com 